\title{
Internet resources for Latin American studies
}

\author{
By Molly Molloy
}

\section{An introductory list of resources}

$\mathbf{T}$ he following Internet resources have been identified as potentially useful for Latin American studies. As a discovery tool, the Kovacs "list of lists" (see below) proved especially useful. I also used Gopher, Archie and WAIS to explore various file archives. The LIBS software (created by Mark Resmer of Sonoma State University and available via ftp from sonoma.edu in the / pub directory) aided the exploration by facilitating telnet connections to library catalogs, gophers, Archie and WAIS servers. In addition to these tools, I find that one of the best ways to discover Internet resources is to subscribe to several discussion lists or newsgroups that look promising; post queries and then follow up on new sources as they are announced.

The list below is not intended to be complete. I encourage readers to contact me about other sources.

\section{Lists of lists}

Kovacs, Diane [and others]. Directory of Scholarly Electronic Conferences [ftp document, electronic mail file, hypercard stack]. 6th revision ed. Kent, Ohio: Kent State University Libraries; 1993; c1992.

Files can be retrieved via e-mail or ftp. Send e-mail messages to <listserv@kent vm.kent.edu> with the message line: <get filename.filetype $>$. To retrieve via $\mathrm{ftp},<\mathrm{ftp}$ ksuvxa.kent.edu > in the <library> directory. $<$ ACADLIST.FILE2 $>$ contains the area studies lists, including many on Latin America. FILE2 also includes the library science lists.
McGee, Arthur R. African, African American, African-Caribbean, African Latin Internet/ Bitnet Mailing Lists [ftp document].

Retrieve latest version of this list-of-lists via ftp from: <ftp.netcom.com $>$ in the directory: <pub/amcgee>. Also available via e-mail to: <mcgee@epsilon.eecs.nwu.edu>. Art McGee regularly posts updates of this list to many of the Latin American interest groups and other e-mail discussions. The list includes many of interest to Latin Americanists.

\section{Electronic mail discussion groups}

ACTIV-L: Peace, Democracy, Freedom, Justice. To subscribe: <listserv@mizzou1.missouri.edu> To send messages to the list: <activ-1@ mizzou1.missouri.edu>.

Covers progressive/radical political issues globally. Of interest to Latin Americanists because many human rights, environmental, and labor groups post news and bulletins from Latin America.

ARGENTINA To subscribe send message to <argentina-request@asterix.eng.buffalo.edu>. Messages to list <argentina@as terix.eng.buffalo.edu $>$. A separate address is used for news <argentinanoticias@ ois.db.toronto.edu>

BORIKEN: Puerto Rico Culture \& Society. To subscribe send message to: <listserv(i) enlace.bitnet>. Messages to: <boriken@ enlace.bitnet>. For other list and subscription information contact: Rafael Pirazzi <r_pirazzi@upr1.upr1.clu.edu>.

BRAS-NET: Brazilian Discussion Group/Network. To subscribe send message to: <brasnet-request@cs.ucla.edu>. Several other Brazilian interest groups exist. To get more general info on these other lists, try sending an e-mail message to: <gomide@brfa 
pesp.bitnet> or to: <listserv@fapq.fapesp.br>. CENTAM-L: Central America Discussion Group.

To subscribe: <listserv@ubvm.cc.buf falo.edu>. Post messages to <centam1@ubvm.cc.buffalo.edu > News, human rights reports and other information posted regularly from the region.

CHILE-L: Chile Discussion Group. To subscribe send message to: <listserv@usachvm1.bit net>. Post messages to: <chile-1@usa chvm1.bitnet>.

DEVEL-L: Technology Transfer in International Development. To subscribe: <listserv @auvm.american.edu>. Post messages to: $<$ devel-1@auvm.american.edu>Administered by Volunteers in Technical Assistance. For more information contact: <vita@gmu vax.gmu.edu>. Exchange of information on technology and development. Good source for finding out about publications (electronic and otherwise).

ECUADOR: Ecuadorean Network. To subscribe send a message to: <rone@skat.usc.edu> To post messages: <ecuador@skat.usc.edu>. Daily news bulletins posted to the list.

FOLLAC: Folklore Latino, Latinoamericano y Caribero. Discussion of Latin American Folklore. To subscribe send a message to Emily Socolov at: <owner- follac@ccwf.cc.texas .edu>. To post messages to the list send to $<$ follac@ccwf.cc.utexas.edu>.

GNET: Global Networking. Note: To subscribe send message to: <gnet- request@dhvx20 .csudh.edu>. Announcements of research papers and other documents available from the GNET Archives, an ftp site <dhvx 20.csudh.edu $>$. The archive contains papers on global networking, use of networks in less developed countries, communication in international development, etc.

LALA-L: Latin Americanist Librarians' Announcements List. To subscribe: <listserv@uga. cc.uga.edu>. Messages to: <lala-1@ uga.cc.uga.edu>. Moderator: Gayle Williams <gwilliam@uga.cc.uga.edu>

LASNET: Latin American Studies Network. To subscribe send a message to: <lasnetrequest@emx.utexas.edu>. Post messages to: <lasnet@emx.utexas.edu>. Moderator: Ning Lin<ilasut@emx.utexas.edu>. Purpose of LASNET is to facilitate communication among Latin Americanists internationally. Includes directory.

LATCO: Business \& Trade with Latin America. Latin American Trade Council of Oregon. To subscribe send a message to: <lserv@psg.com>. To post messages to the list: <latco@psg.com>. Moderators: Tom Miles <tmiles@well.sf. ca.us> and Walter Morales <walter@psg. com $>$. Discussion list for trade and economic data, analysis, opinions and experience, information source on Latin American business.

MEXICO-L: Knowing Mexico: People, Places \& Culture. To subscribe: <listserv@tecm tyvm.mty.itesm.mx $>$. To post messages: <mexico-1@tecmtyvm.mty.itesm.mx>.

NATIVE-L: Indigenous Peoples Information; NAT-LANG: Languages of Indigenous Peoples; NATCHAT: Indigenous Peoples Discussion. Three separate lists available for subscription via: <listserv@-tamvm1 tamu.edu>. These lists deal with various issues related to indigenous peoples worldwide. Politics, culture, information sources are all discussed. Good news source for environment, human rights, politics, etc. in Latin America, especially for Guatemala, Brazil, Ecuador, Peru and other countries with large indigenous populations.

PERU: Discussion Group. To subscribe send message to: <owner-peru@cs.sfsu.edu> Post messages to: <peru@cs.sfsu.edu> List administrator: Herbert Koller <herb@busy be.sf.ca.us>.

USENET NEWS on Latin America: <soc.culture.latin-america>, <soc.cul ture.mexican $>$, <soc.culture.caribbean $>$, $<$ alt.culture.argentina $>,<$ soc.culture .portuguese>, and <soc.culture.spain> [usenet newsgroups]. Note: To read USENET news you must have access via a news reader on your local system or through access to another system. Find out about local access by contacting your computer center. These newsgroups discuss almost anything relating to society, politics, travel, culture, etc. for the regions described. Various languages, mostly Spanish and English. Much information is cross-posted to other lists.

\section{Special files and other resources}

NAFTA: North American Free Trade Agreement. The full text of the NAFTA document is available from several ftp archives including: <ariel.unm.edu>, <csf.colorado.edu>, and <athena.law.columbia.edu>. An Archie search yielded only the ariel site, but the other addresses were given as answers to (continued on page 399) 


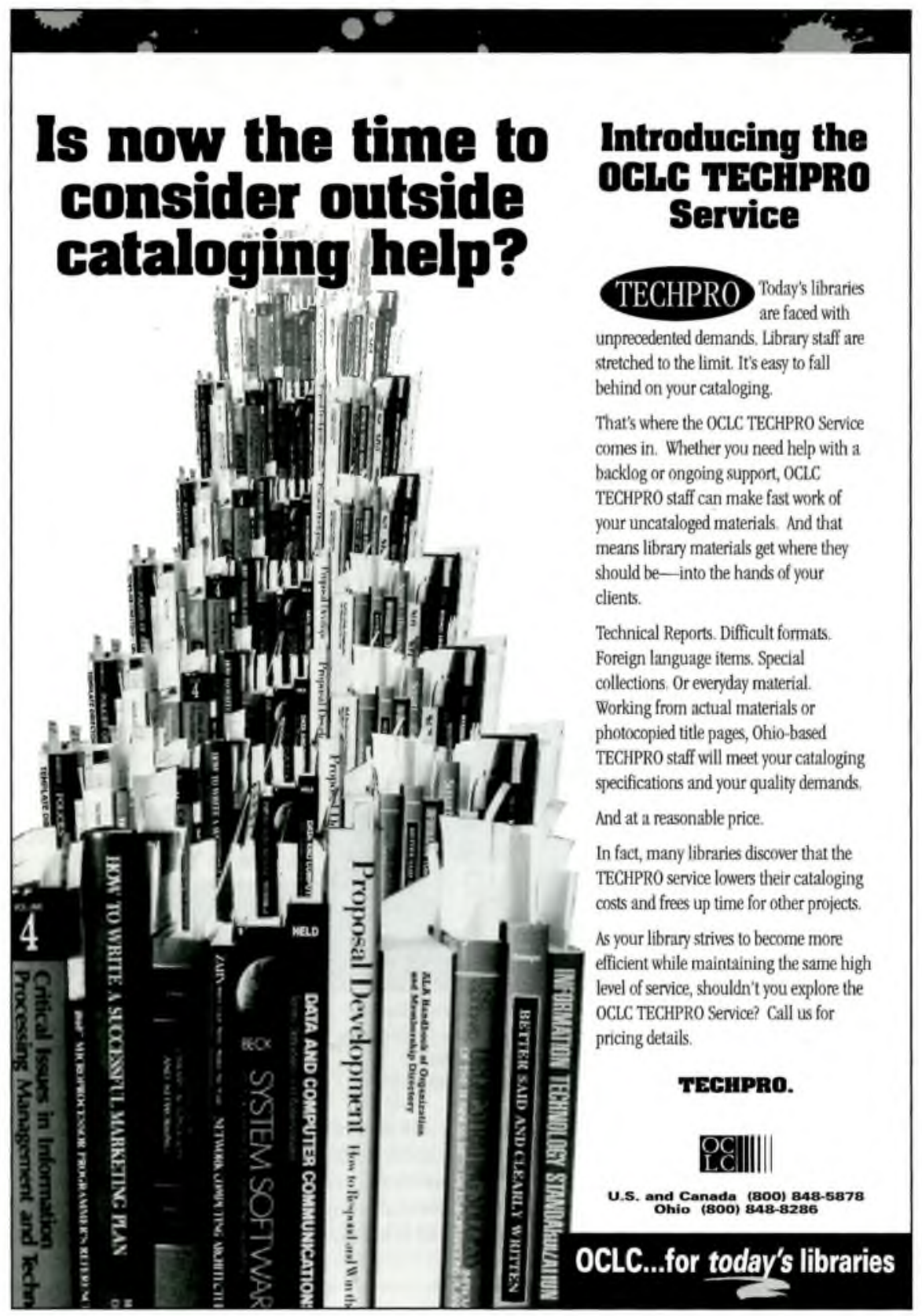




\section{Student reaction to the Electric Undergrad}

So far students have responded positively to the Electric Undergrad, but there are plans to conduct a study. It is fascinating to see how they are examining the latest "technological toy" in the Undergraduate Library. Instructors are beginning to request that students use the Electric Undergrad instead of the library tape tour. However, it will not replace the audio tape tours, but presents a new alternative.

As academic libraries move towards Computer Assisted Instruction (CAI), we believe the Electric Undergrad will be one of the successful programs to emulate for interactive library orientation.

According to Bob Wedgeworth, interim university librarian, "The Electric Undergrad is only the first step in an evolving series of developments that will transform the Undergraduate Library into a multi-media laboratory for research and study. Among the benefits we expect to realize will be a more independent undergraduate student, capable of identifying and satisfying their information needs, whether they are course-related or intended to satisfy their own desire to learn more."

Electric Undergrad began two years ago when Media/Microcomputer Librarian Dennis Norlin (currently director of the Devereaux $\mathrm{Li}$ brary) received one of the first IBM Innovations Grants from a campus-wide committee promoting the use of interactive computing in undergraduate instruction. Additional funding for the program was provided by a grant from the Chancellor's Parents' Fund.

\section{(Internet resources cont. from page 396)}

various net inquiries. The NAFTA document is quite long and unless you have a lot of disk space available and facility for electronically storing and searching the document, you may not want to retrieve the files via ftp. You can however, search and retrieve relevant portions of the text via WAIS (Wide Area Information Server) at <sparc-1.law. columbia>.

WAIS Information of Interest to Latin Americanists. To connect to WAIS: <telnet 192.31.181.1 or quake.think.com> Login: wais. The LIBS software described above provides seamless access to WAIS. WAIS

\section{Feature your collection on the cover of C\&RL News}

CERL News wants to feature aesthetically pleasing photos of items from library collections on its covers. If you have material in your library's collections that you think would make an attractive CGRL News cover, please send us a photograph and a brief description of the item and the collection. Photos may be either color or black and white and should be $5^{\prime \prime} \times 7^{\prime \prime}$ or $8^{\prime \prime} \times 10^{\prime \prime}$. Illustrations with a vertical orientation work best. Materials submitted will become the property of CERL News and cannot be acknowledged. Send to: CERL News Covers, 50 E. Huron St., Chicago, IL 60611. allows keyword access to hundreds of archived electronic files. Browse the list to see what is available. WAIS sites and searchable files change constantly. The following files and sites currently available may be of interest to Latin Americanists: <nafta at sparc1.law.columbia>, <us-budget-1993 at sunsite.unc.edu>, <columbia-spanish-lawcatalog at pegun.law.columbia.edu $>$ $<$ clinton-speeches at sunsite.unc.edu $><$ usstate-department-travel-advisories at gopher.stolaf.edu>, and <worldfactbook(CIA) at cmns-moon.think.com>. You can also search the Kovacs list of Academic E-mail Conferences via WAIS <academic_email_conf at munin.ub2.lu.se> GOPHER UT-LANIC: Latin American Network Information Center. Produced by the University of Texas-Austin, Institute of Latin American Studies. Access via telnet: $<$ telnet lanic.utexas.edu> Login: <lanic> You can also access via any gopher server with a menu system that allows access to "all gophers in the world." Choose North America, Texas, etc. Announced in April 1993, the experimental UT-LANIC gopher offers a menu that will provide access to Latin American databases, access to library catalogs and other services. When complete it will include a directory of databases by subject and will provide automatic access through pointers. For more information contact: Ning Lin, LANIC Technical Director <nlin@bongo .cc.utexas.edu> or Carolyn Poage <carolyn@emx.utexas.edu>. 